\title{
CONTENT OF FUTURE ECONOMISTS' PROFESSIONAL MOBILITY IN RESEARCHES OF FOREIGN SCIENTISTS
}

\begin{abstract}
The content of professional mobility of future economists in the writings of foreign scientists have been presented. The components of future economists' professional mobility formation have been considered. It has been established that the possession of a combination of these components enables future specialists to achieve a high level of generalized professional knowledge, improve them and acquire them on their own, and also determines the ability to set professional goals, choose ways to achieve them and to control this process. It has been determined that an integral part of professional mobility is the activity of a person, professional development and personal growth of the learner. A professional mobile specialist who is capable of professional development, possessing theoretical knowledge in the field of economics and other basic sciences, is able to critically treat information, find and use information rationally, organize his day-to-day educational and professional activities, independently and promptly solve the task of a problem nature, quickly switch from one activity to another. It has been established that a professionally mobile specialist should be capable of professional development, be theoretically knowledgeable in the field of economics and other basic sciences, critically treat information, find and use information rationally, organize his day-to-day educational and professional activity, solve problems independently and promptly, quickly switch from one activity to another. As the modern labor market necessitates the training of specialists in various fields of activity, it substantiates the requirements for the formation of social and professional qualities of a future specialist on the basis of general knowledge, as well as on the development of the ability to solve non-standard professional tasks, think alternatively, constantly be ready to improve professional activity and specialists' training, be capable of constant development for performance of various tasks.

Keywords: professional training, professional mobility, professionally mobile specialists, specialists in economics, professional development, higher education, professional education, economic development.

\section{INTRODUCTION}

A dynamic socio-economic sphere requires constant changes in the labor market, so there is a need for training specialists who are able to adapt to a changing environment, be competent, mobile, and competitive.

Due to the fact that in modern conditions higher education is not a guarantee of employment because of rapid socio-economic and technical development, self-education and self-development are the main priorities. Professionally mobile specialists, capable of professional development, possessing theoretical knowledge in the field of economics and
\end{abstract}


other basic sciences, are able to critically treat information, find and use information rationally, organize their day-to-day educational and professional activities, solve problems individually and promptly, switch quickly from one type of activity to another.

\section{THE AIM OF THE STUDY}

The aim of this paper is to study and present the results of comparative scientific and pedagogical researches of foreign scientists to determine the content and theoretical substantiation of the structure of future economists' professional mobility; to define the notion and the content of the "professional mobility of future specialists in economics" concept and its role as an important professional quality in the process of training future specialists in a modern higher education institution from the experience of foreign scholars; to study the importance of professional mobility of future economists in their further professional activities.

\section{THEORETICAL FRAMEWORK AND RESEARCH METHODS}

It is important to note that the problem of training professionally mobile specialists was studied by R. Bendix (1959), K. Davidson (1997), E. Durkheim (1996), L. Goriunova (2006), O. Kipina (2009), S. Lipset (1959), N. Merzliakova (2009), W. Moore (1997), T. Parsons (2000), M. Sokolova (2001), L. Soldatova (2014), P. Sorokin (1992), E. Starshinova (2011), T. Zaslavskaia (1974).

Each of them made a great contribution to the definition of "professional mobility" term. This article is the result of a study that was conducted by analyzing, comparing, and generalizing of what is needed to study the research work of scientists.

In order to achieve the goal of the research and the solution of the tasks, methods of cognition have been used, which are developed by science and tested on practice on the basis of foreign researchers experience. Methods of analysis, synthesis, comparison and generalization of original documents and researches of foreign scientists have been used.

\section{RESULTS}

According to United Nations Educational Scientific and Cultural Organization (1999), the reform and development of higher education presuppose three major trends that are common to education systems around the world: the quantitative increase in the number of students and the preservation of inequality at the international and regional levels for access to education; diversification of institutional structures and forms of education; financial difficulties in the activities of educational institutions. One of the basic principles of modern educational policy is mobility.

The concept of "professional mobility" appeared in scientific literature in the middle of the $20^{\text {th }}$ century. Initially, it meant changing a variety of activities or professions. As a result of research by American sociologists R. Bendix and S. Lipset, professional mobility gained the status of an independent subject (Lipset \& Bendix, 1959). Analyzing the works of E. Durkheim, we have determined that the main factor for social progress is the division of labor (Durkheim, 1996). The scientist noted that the individualization of social behavior associated with the strengthening of the division of labor is reflected in the concept of "plasticity", which means the ability and possibility of an individual to form their work and professional perspectives.

Socio-economic changes lead to a rethinking of educational priorities for the training of a new type of specialist - a mobile, competent, competitive, capable of being oriented in the modern world, freely dispossessing its professional qualifications and adapting easily to the new conditions of professional activity. The current socio-economic situation of the country's development requires high-level employees with professional mobility. One 
of the most important areas of human life is the professional field in which professional mobility plays an important role as it determines readiness for work. However, the existing system of professional education is not sufficiently aimed at training a professionally mobile specialist. Thus, this problem becomes more and more important and relevant. The study of professional mobility of specialists has a systemic multilevel character and is determined by economic, socio-cultural and political factors (Merzliakova, 2009).

On the one hand, the professional mobility of a specialist is the result of the study, and on the other - the factor that determines it. Formation of an active type of personality is a condition for its further involvement in professional activities.

The term "mobility" (mobils - from Latin) has several definitions, among which the most important is the ability to move quickly, act quickly, make decisions, navigate quickly, independently in different circumstances to find a quick solution to problems.

According to the analysis of scientific sources, the term "mobility" is interdisciplinary and is used by experts in philosophy, economics, sociology, psychology and pedagogy (Parsons, 2000). The motivation and desire to move into more interesting positions in the profession that are more functionally important are of great importance to the individual (Davidson \& Moore, 1997).

The famous teacher J. Pestalozzi compared mobility with flexible adaptability and identified it with "obedience and supportive modesty", because he believed that these qualities are the most important knowledge that a person must possess. The scientist has determined that flexible adaptability and preparedness for different types of labor will be advantages in a profession (Pestalozzi, 1989).

Great contribution to the study of professional mobility was made by P. Sorokin. The scientist has determined that professional mobility is some transition of an individual or a social object from one social position to another. Social mobility is divided into two main types: horizontal and vertical. Horizontal social mobility or movement is the transition of an individual from one social group to another, located at the same level. Vertical social mobility determines the relations that arise when moving a person from one social stratum to another. Depending on the directions of the transition, vertical mobility may be ascending or descending. The ascending form determines the social growth of the individual, that is, the transition from the lower level to the higher. Accordingly, the descending is a decline in the social status (Sorokin, 1992).

In Ukraine and abroad, great attention is paid to the problem of the quality of higher education, which largely ensures professional competitiveness in modern labor market.

The direction of education to the person, increasing its role in the development of the state and society, depends not only on the high level of his/her overall training, but also on the professional one. It is necessary to change the approach to the goals, content, organizational structure of specialists' professional training in the system of vocational education. It should take into account the change of the main goal of society, interdisciplinary nature of professional work, personal orientation in continuous education, interest of society in educated citizens with a high level of pedagogical training as a guarantor of their successful professional career and competitiveness in the labor market (Goriunova, 2006).

Analyzing professional mobility from the experience of foreign scientists, we can determine that it is an active component of the personality. The professional and personal formation of learners is carried out through their own activity. In this case, the activity is expressed both as work and self-transformation, as well as the transformation of the 
environment. The activity is manifested in the ability to set goals, implement them, despite the circumstances and obstacles. Formation and manifestation of the active life position of the specialist's personality is connected with the development of creative potential (Sokolova, 2001).

Our scientific interest is the study of foreign scientist O. Kipina, who defines professional mobility as a dynamic personality characteristic expressed by the ability to assimilate successfully to change professional conditions, as well as to be ready for selfdevelopment and self-realization in the work process (Kipina, 2009). The scientist offers the following structure of professional mobility:

- active position of a person, which demonstrates self-transformation and transformation of the environment, as well as the ability to set goals and follow programs to achieve them;

- adaptability, which allows to effectively assimilate into the changing conditions of professional activity;

- creativity, which predetermines a constructive attitude to the external environment, readiness to purposefully and adequately change it, a realization of one's own activity (Kipina, 2009).

The scientist T. Zaslavska considers professional mobility as a change of labor position or the role of a specialist due to changes in the place of work or profession. With this approach to the concept of "professional mobility" the following aspects are considered: objective, subjective and characterological (Zaslavska, 1974).

The development of higher economic education is greatly influenced by the rapid development of innovation processes that take place in the European and world educational space. The professional mobility of students is a major factor for increasing the competitiveness and attractiveness of the future profession in the international labor market. The ability to self-development, self-education, self-designing become the main priorities of the modern world. In this way, the problem of the training of professionally mobile professionals, in particular in the field of economics, is becoming acuter.

To determine the pedagogical essence of professional mobility, it is necessary to determine the structural components of this concept, since the formation of professional mobility of a future economist is carried out in stages.

A future specialist in economics must master general cultural and professional competencies, be able to generalize, analyze the data of domestic and foreign statistics on socio-economic processes and phenomena, to forecast and develop themselves, to be able to interact with a professional team, organize the activities of a small group established for the implementation of a specific economic project. Motivation for professional and foreign language skills, possession of professionally oriented communication are of great importance to mobile professional specialists.

It is important to highlight components of the future mobility of an economist: 1) motivational and cognitive; 2) organizational and activity; 3 ) social and communicative. The essence of the motivational-cognitive component consists in the striving for knowledge, the accumulation of knowledge and experience, since, the greater the number of professional knowledge possesses an economist, the higher is his motivation to develop. The cognitive aspect of this component is in the accumulation of knowledge for the formation and further development of professional mobility. An important component of the professional mobility of a future economist is organizational and activity. Obligatory abilities to organize a professional activity, its planning, structuring, designing, forecasting the results and 
consequences are necessary competencies for a modern economist. Organizational and management activity, in turn, is differentiated by management of business, documentation of the enterprise and organization of collective professional activity. Accordingly, for the organization of professional actions aimed at a successful activity, the future economist requires special skills in setting goals, making the right decisions in non-standard situations. The social and communicative component of professional mobility is linked with the need to involve an economist in a professional community, adapting to working conditions. This component is characterized by knowledge of professional ethics, norms of behavior, ability to build a favorable interpersonal relationship with colleagues.

Professional mobility of the future economist is a quality of personality, characterized by his/her desire for professional self-development, mastery of knowledge in economics and other sciences, ability to efficiently organize individual and collective activities, skills of business communication at the international level, use of interactive tools in professional and everyday activities to achieve their goals (Starshynova, 2011).

In order to form and develop the professional mobility of future economists in the educational process it is expedient to apply innovative pedagogical technologies, conduct classes in an interactive form. The interactive teaching methods that promote the formation of future mobility of future economists include: problem-based learning, debate, business games, discussions and quizzes. The use of such innovative techniques contributes to the development and economic thinking. In the forming of students' professional mobility the ability of a future specialist to timely and competently solve problems and make professional decisions in difficult situations is necessary and important.

On the example of "Theory and Practice of Financial Recovery of the Enterprise" discipline, a researcher L. Soldatova developed criteria for improving professional mobility of future economists. The first criterion for effective training of future economists is that at the beginning of the discipline study it is advisable to focus on terminology, assimilation of new economic categories. It provides knowledge and creation of prerequisites for the formation of economic, logical and theoretical thinking, which, of course, contributes to the formation of professional mobility of the future economist (Soldatova, 2014). The second criterion is characterized by practical application of pedagogical technologies. Since problem learning is the most effective means of forming an outlook, it is advisable to use it to form the future mobility of an economist, as in the process of learning which presupposes using interactive methods, dialectical and economic thinking is formed. The third criterion is formed taking into account the interdependence and relevance of theoretical and applied economic and financial problems. The fourth criterion is the effective use of the acquired knowledge in practice, for effective study by future specialists in economic disciplines.

It is expedient to carry out practical tasks on the example of real enterprises, since solving problems in the process of their occurrence in professional activities ensures professional growth of a future economist.

Consequently, the mutual use of the educational situation and the real tools contributes to increasing the efficiency of training and the development of professional mobility of future economists.

\section{CONCLUSIONS}

Thus, by examining the content of the professional mobility of future specialists in economics in the works of foreign scientists, we have concluded that professional mobility is an important quality of a specialist, both in the process of studying at a higher educational establishment and in his/her further professional activities. 
Professionally mobile specialist is able to work effectively and creatively in modern conditions, capable of professional development, and, therefore, is competitive both in the domestic and international labor market. Due to the fact that the education system is rapidly updating and developing, the problem of the training of professionally mobile specialists at the international level, in particular in the economic sphere, is urgent to higher educational institutions. In order to achieve a high level of professional mobility, future specialists must possess qualities, such as the ability to adaption, self-improvement, continuous learning, creativity, and taking an active life and professional position.

Further scientific researches are planned to identify and substantiate the pedagogical conditions for the formation of professional mobility of future economists by means of a foreign language in the process of studying at a higher educational institution.

\section{REFERENCES}

1. Davis, K., Moore, U. (1997). Klas, status i vlast. Prodolzhenie diskusii o razvitie. Nekotorye printsypy stratifikeysyi. Moscow.

2. Durkheum, E. (1996). O razdelenii obshchestvennoho truda. Metod sotsiologii. Retrieved from ttp://www.twirpx.com/file/532665.

3. Goriunova, L. (2006). Professionalnaia mobilnost spetsialista kak problema razvitia obrazovaniia v Rossii. (Diss. kand. ped. nauk). Rostov-na-Donu: Rossiiskii hosudarstvennyi pedahohicheskii institut.

4. Kipina, O. (2009). Professionalnaia mobilnost pedahoha. Pedahohicheskoe obrazovanie i nauka. Retrieved from http://library.ua/m/articles/view.

5. Lipset, S., \& Bendix, R. (1959). Social Mobility in Industrial Society. Berkeley and Los Angeles: University of California Press.

6. Merzliakova, N. (2009). Professionalnaia mobilnost studenta universiteta v contekste politkulturnogo obrazovaniia. Vestnik Bakshyrskoho universiteta, Bakshyr, 3, 1007-1010.

7. Parsons, T. (2000). O structure socialnoho deistviia. Retrieved from http://www.gumer.info/bibliotek_Buks/Sociolog/pars/index.php

8. Pestalotsi, Yo. (1989). Pedahohicheskoe nasledie. Retrieved from http://publ.lib.ru/ ARCHIVES/P/PESTALOCCI_Iogann_Genrih/_Pestalocci_I.G.html.

9. Sokolova, M. (2001). Proektirovanie individualnykh obrazovatelnykh marshrutov studentov $v$ vuze. (Diss. kand. ped. nauk). Arkhangelsk: Lomorskii hosudarstvennyi universitet im. M.V. Lomonosova.

10. Soldatova, L. (2014). Formirovanie professionalnoi mobilnosti budushchego ecomomista. Vestnik Orenburhskoho gosudarstvennoho universiteta, Orenburg, 2 (177), 156-159.

11. Sorokin, P. (1992). Chelovek. Tsivilizatsiia. Obshchestvo. Sotsialnaia mobilnost, ee formy ifluktuatsii. Moskva: Politizdat.

12. Starshynova, E. (2011). Stryktura professionalnoi mobilnosti budushcheho ekonomista. Pedagogika i psikholohiia. Vestnik Orenburhskoho gosudarstvennoho universiteta, 3(51), 189-190.

13. United Nations Educational Scientific and Cultural Organization. (1999). Statistical Yearbook. Paris.

14. Zaslavskaia, T. (1974). Trudovaia mobylnost kak predmet ekonomikosotsiolohycheskoho issledovaniia. Metodolohycheskie problemy sotsiolohicheskoho issledovaniia mobilnosti trudovykh resursov. Novosibirsk: Nauka. 